\title{
INDIRECT COERCIVE TRANSFER AND EDUCATIONAL COPYING UNDER DICTATORSHIP: THE CASE OF TUNISIA
}

\author{
Tavis D. Jules ${ }^{1}$ \\ Loyola University Chicago, USA
}

Donia Smaali Bouhlila

University of Tunis El Manar, Tunisia

\begin{abstract}
This paper adds a different dimension to the educational borrowing, lending, and transfer literature by examining the consequences of educational reforms that are implemented under dictatorships and their lasting impacts. In using Tunisia as an example, we assess the effects of the 2008 Licence-Maitrise-Doctorat ( $[$ LMD $]$ Bachelor-Master-PhD) reform under Tunisia's former dictator, Zine El Abidine Ben Ali (from 1987 to 2011). The use of coercive transfer and subsequent implementation of LMD reforms by Ben Ali's government were in response to the creation of the European Higher Education Area in 1999 under the Bologna Declaration, which was adopted by twenty-nine European countries. The justification for the indirect coercive transfer of the Bologna model was to ensure the quality of higher education, to encourage student and teacher mobility, to facilitate both the equivalence of diplomas and young people's integration into the labor market. In what follows, we seek to construct a typology of the consequence of wholesaling adopting a reform without tailoring it to the local needs. In this typology, we account for the processes of policy mobilization, local articulation and ownership, structural factors, and path dependency by discussing the power relations through which indirect coercive transfer occur. In doing this, methodologically, we use a comparative-historical approach to Tunisia's higher education policy discourse. Theoretically, we seek to advance the literature of indirect coercive transfer by concluding as to the different factors that should be considered in North-South policy borrowing and transfer.
\end{abstract}

Keywords: Indirect Coercive Transfer, Educational Copying, Comparative-Historical Approach, Tunisia, Licence-Maitrise-Doctorat (LMD)

${ }^{1}$ Correspondence: 820 N. Michigan Avenue Chicago, IL 60611, USA: Email: tjules@luc.edu. 


\section{Introduction}

In 2008, Tunisia - home of the 2011 Arabic Awakening - introduced the Licence/Master's/Doctorate - LMD (corresponding to BA/MA/PhD) with its modularized credit system, aimed at reforming the public higher education sector (consisting of 13 Universities - inclusive of 203 faculties, specialized schools, and higher education institutes, as well as 66 private institutions in 2016-2017). In theory, this reform repealed the old system with the goal of training a new branch of students for the job market. In reality, however, it sought to replicate the existing French system without adequately understanding the consequences and politics of indirect coercive policy transfer. While this reform did create necessary skills for the current labor market, it also provided the impetus for al-sahwa (the uprising or Jasmine Revolution) that toppled President Zine El Abidine Ben Ali in 2011, creating a tsunami of change as it spread across the globe; toppling regimes in Egypt, Libya, and Yemen; nurturing uprisings in Bahrain and Syria; encouraging major demonstrations in Algeria, Iraq, Jordan, Kuwait, Morocco, and Oman; and facilitating minor rebellions in Lebanon, Mauritania, Saudi Arabia, Sudan, and Western Sahara (Jules \& Barton, 2018).

While al-sahwa started with the self-immolation of the street vendor Mohamed Bouazizi in December 2010 and had its historical foundations in the suppressed 2008 Gafsa uprisings, it was the university students who lead the call for change as unemployment boomed among university graduates. In fact, between 2000 and 2007, tertiary education in Tunisia increased by 102 percent, resulting in a 32 percent gross enrollment rate (GyimahBrempong \& Ondiege, 2011). So, the 2008 higher education reforms were a policy Band-Aid to combat the twin challenges of rising unemployment and inadequately trained university graduates. In other words, prior to the enactment of this reform, not enough information had been collected about the school-to-work transition in Tunisia given that the Tunisian labor market had been profoundly transformed under the leadership of Ben Ali's regime. This transformation was a result of internal threats during the early 1980s (demographic, political, and economic developments) and external realignment with structural adjustment programs (SAPs) aimed at privatization, deregulation, and the liberalization of the economy.

When compared to its closest counterparts on the African continent (South Africa and Kenya), Tunisia spends almost twice as much (about 2 percent of GDP) on higher education. In comparison to the Organisation for Economic Co-operation and Development (OECD) countries, which spend on average 1.5 percent of their budgets on university research and laboratories, Tunisia spends approximately 2 percent on improving its outdated and dilapidated facilities (Jules \& Barton, 2018). Yet, Tunisia does compare its higher education system with other African countries since Tunisian officials, both pre-al-sahwa and post-alsahwa era, have always aimed to design a world-renowned system regarded as the "standard bearer of sciences, knowledge and research" (MOHESRT, 2008, p. 15).

Since independence, the Tunisian Higher education system has aimed to provide sound academic training. Access to higher education is determined primarily by a score obtained on the baccalaureate exam, which is usually 10 out of 20 or higher. Additionally, enrollment in institutions of higher education is allocated based on student preference and the baccalaureate score. The state essentially guarantees free higher education, with the exception of some user fees across the country's 13 public universities. The demand for higher education increased as a result of the growing 20-24-year-old population and rising retention rates in basic and secondary education. According to the ministry of higher education, the student population increased from 226,000 in 2002 to 340,000 in 2012. The number of female students reached 209,000 , or 61.5 percent of the overall students. 
The Tunisian higher education system is composed of multidisciplinary universities and a network of Higher Institutes of Technological Studies. However, in 2008, when the system was unable to meet the labor market demands, the Ben Ali regime sought reform by looking North to Europe for inspiration, as Europe too was transforming its transnational higher education system under the Bologna process. The Ben Ali regime aimed to prepare Tunisians for the European labor markets, an outcome that was ultimately flawed in both its design and outcome. It is within this context that we explore the consequences of "uncritical international transfer," given its lack of institutional capacity and Franco-aid dependence (Crossley, 1984; 1999; Crosley, Bray, Packer, \& Sprague, 2011; Holmes \& Crossley, 2004; Jules, 2015; Lam, 2010; Louisy, 200l). As such, the influential work of Dolowitz and Marsh (1996) highlights the importance of policy transfer.

Building upon earlier work in comparative and international education on "education transfer" (Beech, 2006, 201 1, 2012; Fryer \& Jules, 2013; Jules, 2008; Rappleye, 2006; Rappleye \& Paulson, 2007; Robertson, Bonal, \& Dale, 2002), this paper examines the uniqueness of the Tunisian case of wholesale policy transfer gone wrong, even when the core fundamental, institutional, and cultural attributes for the transferred policy exist in the form of a vibrant post-colonial apparatus. However, we use the notion of "indirect coercive transfer" (Bazbauers, 2017; Evans, 2009; Jules \& Silva, 2008; Stone, 2001) to exemplify path dependency through the ways in which governments are pressured to enact educational reforms when they are dependent on donor support and aid from former colonies.

As such, this paper employs the emerging typology of indirect coercive transfer to examine how Tunisia chose to copy the Bologna higher education reforms, which created the European Higher Education Area (EHEA) and currently involves a total of 48 countries. In emulating the core tenets of EHEA, Tunisia sought to show Europe that it was ready to integrate and gain access to the European single market. The focus is then on "why;" to be sure, the structural factors which led to an indirect coercive transfer in Tunisia to stimulate policy innovation. While several scholars have explored the implication of the Bologna process from a regulatory perspective (Jayasuriya \& Robertson, 2010), compared it with other regional and supranational educational strategies (Verger \& Hermo, 2010), examined its impact on post-socialist countries (Silova, 2009), and discussed its global dimensions and global referencing reflex (Hartmann, 2008; Marginson \& Wende, 2007), little attention has been paid to indirect coercive transfer, which is a process neighboring countries are forced to use as they seek access to Europe's extensive market. Taking this gap in attention into consideration, this paper aims to reexamine the ways in which education transfer is sometimes unsuccessful, even if implicit or explicit references are made or not made to the original policy, and why it fails when it has institutional and policy support from elites, stakeholders, and clients. Historically, Tunisia's two dictatorial regimes have used higher education to expand access to the middle class.

In examining why Tunisia chose to look North to Europe in 2008 as it reformed its educational system, this paper uses a comparative-historical approach to draw attention to "the processes over time and the use of systematic and contex tualized comparison" (Mahoney \& Rueschemeyer, 2003, p. 10) of education policy priorities. Since national policies articulate the values of those in power, we focused methodologically on text production, distribution, and consumption of policy talk on the discursive level by studying the Ben Ali's regimemandated policy discourse across texts dated 1987 to 2011 (Ball, 1990). In employing such an approach, we focused on the level of discourse with the aim of understanding the "processes [of the policy documents] and [to explore its] causal determinants ... through a detective- 
style analysis which seeks to highlight the causal impact of particular factors within particular cases" (Lange, 2013, p. 4).

Our aim was to "study through" by "tracing ways in which power creates webs and relations between actors, institutions and discourses across time and space" (Shore \& Wright, 1997 , p. 14). In order to follow "the source of a policy - its discourses, prescriptions, and programs - through to those affected by the policy," we elucidate "the cultural and philosophical underpinning of the policy" (Wedel et al., 2005, p. 40). In what follows, we first present an overview of the typology employed. Next, we discuss the history of higher education in Tunisia, and then discuss the context that was the impetus for indirect coercive transfer. We then shed light on what is copied and what is not copied under the process of indirect coercive transfer, and, finally, conclude the paper by addressing the complexities of indirect coercive transfer upon the current system.

\section{Indirect Coercive Transfer and Educational Copying}

Much of the research in comparative and international education suggests that when countries are at a crossroads they will look to other nations for policy ideas, models, and suggestions that manifest in policy transfer, as well as lesson-drawing (Rose, 1993; Jules, 2010; 2015), and educational borrowing and lending (Phillips \& Ochs, 2004; Steiner-Khamsi, 2004; Steiner-Khamsi \& Waldow, 2012). Historically, policy transfer has been expressed as voluntary transfer, lessons-drawing, negotiated transfer, or direct coercive transfer (Evans, 2009). Although disputed by some, we have come to accept the definition of policy transfer as "the process by which knowledge about policies, administrative arrangements, institutions and ideas in one political system (past or present) is used in the development of policies, administrative arrangements, institutions and ideas in another political system" (Dolowitz \& Marsh, 2000, p. 5).

However, embedded within the education transfer typology in comparative and international education is the reason countries gaze externally for policy ideas in the form of "cross-national attraction" (Phillips, 2004). While there is a well-established typology (ranging from political revolutions, systemic breakdown, endogenous unhappiness, adverse exogenous reviews, and new arrangements and coalitions in the aftermath of upheaval) among countries that borrow and lend policies in market-oriented economic systems, the borrowing country is often viewed as a passive recipient (Phillips, 2004; Phillips \& Ochs, 2004). Following this line of thinking, we suggest that indirect coercive transfer, which results "from transnational policy externalities and mutual interconnectedness between states" (Benson \& Jordan, 2011, p. 370) as well as other push factors such as internal consensus and global economic pressures, may lead to similar policy responses in both market-based systems and dictatorships (Bache \& Taylor, 2003; Dolowitz \& Marsh, 1996; Evans, 2009).

In this way, indirect coercive transfer occurs when "policy adopters and adapters experience pressures from powerful external stakeholders in the form of policy discourses, target setting, monitoring, evaluation, and best practice" (Xheneti \& Kitching, 2011, p. 1032) because they fear falling behind neighboring countries or what Ikenberry (1990) calls policy "bandwagoning." While indirect coercive transfer has received some attention in postsocialist studies (Xheneti \& Kitching, 2011), it has not been applied to the movement of educational ideas between states in comparative and international education. Moreover, transfer is often described as a voluntary endeavor in market-based economies that is driven by the activities of powerful states and "international knowledge banks" (Jones, 2004), whereas its objectives are not always discernable. 
While the policy transfer literature lists several "hard transferable elements" (Dolowitz, 2003; Jones \& Newburn, 2006) ranging from "policy goals, structure and content, policy instruments or administrative techniques; institutions; ideology; ideas, attitudes and concepts; and negative lessons" (Dolowitz \& Marsh, 1996, pp. 349-50) others suggest that the "soft transfer" (Stone, 2004) of "ideas, ideologies, and concepts; elements of 'policy' that circulate freely among non-state actors under conditions of greater globalization” (Benson \& Jordan, 2011, p. 370) is proliferating. Thus, our focus is on the power relations of policy transfer and its motivations in dictatorial settings. The orthodox literature on transfer often reflects the idea that coercive policy transfer is global (and involves international knowledge banks) rather than regional (using supranational entities).

Rose (1993) suggests a continuum of the degrees of transfer ranging from copying, emulation, hybridization, synthesis, and inspiration, which was later updated to include photocopying, copying, adaptation, hybrid, synthesis, disciplined inspiration, and selective imitation (Rose, 2005). Bulmer et al., (2007) advise that copying and emulation results in 'hard' coercive transfer under the process of Europeanisation. Following Fryer and Jules (2013), this paper explores African contextual scenarios which feature indirect coercive educational transfer in the form of goals, targets, and instruments. In that vein, we want to suggest that educational copying is about more than borrowing and implementing aspects of Western-centric policies and in several cases "indigenizing" (Vavrus, 2004) to fit local contexts. As Bennett (1991) proposes, there is a "natural tendency to look abroad" when policymakers are dissatisfied with domestic reforms. Others, such as Rose (2006), recommend that in instances where policy causes 'externalities,' when a specific country feels obligated to adopt another country's policy if the two countries share common traits.

This external pressure is often referred to as indirect coercive transfer in that it compels actors to adopt new strategies. Thus, indirect coercive transfer or what we call educational copy is the wholesale transfer - lock, stock, and barrel - of an external reform into a similar context, and, in this case, a viable postcolonial apparatus that had not changed much since the end of colonialism. Unlike policy borrowing where partial (not full) policy transfer occurs through "selective or discursive borrowing or lending" (Steiner-Khamsi, 2004, p. 14) in market-oriented systems, educational copying is about the full transfer of policy priorities. Thus, educational copying is different from educational transfer in that it is not penetrative nor based on cohesion, but, rather, something that is done voluntarily, or what others have called "lessons-drawing" (Rose, 1991; Jules, 2012; 2015). Therefore, educational copying sits on the Dolowitz and Marsh (2000) continuum, which ranges from lessondrawing (perfect rationality) to coercive transfer (direct imposition) as an act of "bounded rationality" in that it is voluntary. In this manner, indirect coercive transfer and educational copying point to the interdependence of states and governments in tackling shared externalities with similar strategies.

We also recognize the limitations of the concept of policy transfer (DussaugeLaguna, 2012) and that other authors speak more to "policy mimesis" (Massey, 2009), "institutional transplantation" (Mamadouh et al., 2003), or "policy mobilities" (Peck \& Theodore, 2010); therefore, we too can easily speak of 'indirect coercive policy borrowing,' 'indirect coercive policy mobilities,' or 'indirect coercive institutional transplantation.' However, for us, the conceptual name of the typology is not as essential as the process, of which we argue is neither voluntary nor equal. We suggest that educational copying through indirect coercive transfer does not occur through haphazard implementation by passive recipients, but, rather, is implemented consciously by active agents. Unlike policy borrowing, indirect coercive transfer is about policy assimilation into the dominant patterns through 
networks across multiple scales driven by government-centric processes implemented at numerous sites and by numerous actors. These sites and actors must be understood "not as discrete territories but, rather, as unbounded, dynamic, relational assemblages" (Mccann \& Ward, 2012 p. 327). As such, indirect coercive transfer is initiated by several actors, endogenous or exogenous, to develop a policy to address a perceived issue/problem, while acknowledging that the host site is equipped to handle the reform.

\section{Higher Education Reforms and Authoritarian Bargaining Agreement in Tunisia}

Today, the higher education system falls under the Ministry of Higher Education, Scientific Research and Technology (MOHESRT). Both public and private higher education institutions are open to all students who have completed their secondary education and have been awarded the Diplôme du Baccalauréat. While Tunisia has private universities that are regulated under the Higher Educational Framework of 1989 and Law 4 of 2008, they are not viewed as comparable to the thirteen state universities (including the Virtual University). Moreover, there are three main types of institutions of higher education: faculties (facultés), institutes (instituts) and specialized schools (écoles), found in the public higher education system. The primary fields of higher education studies are Basic science and technological studies; law; economics and management sciences; languages; humanities and social sciences; arts; education; tourism; journalism; sports; agricultural sciences; biotechnology; environmental studies; medical and paramedical studies. The current system has faced much contestation as to the best type of education for Tunisians at the tertiary level.

Tunisia's higher educational system is one of the oldest in Africa and dates to the founding of Madrasat al-Zitouna (today Ez Zitouna University) in 732 BCE. Madrasat alZitouna, with its Arabic language and Qur'an-based curriculum, appealed to both local and international students who later took positions as Islamic teachers, judges in Sharia courts, or became members of the Ulama ranks (an exclusive group of religious leaders) (Green, 1978; Jules \& Barton, 2014; Micaud, 1964). Madrasat al-Zitouna were small institutions of learning connected to local mosques (masjids), which emphasized rote memorization and were privately funded. It was during the "Islamic golden age" (from the eighth to the thirteenth century) that higher education flourished in Tunisia and tremendous advances were made in mathematics, arts, and medicine. The next set of reforms in higher education occurred during the era of Ahmed Ibn Mustafa (from 1837 to 1855) of the Husainid dynasty, who concentrated his efforts on "introducing administrative, staff, teaching and financial measures designed to make the pursuit of Islamic knowledge more systematic and stable" (El-Mesawi, 2008, p. 50) as well as building public libraries.

In 1881, when the Treaty of Bardo was signed between France and Bey Mohamed Sadok, establishing a French Protectorate which was later extended under the 1883 Convention of La Marsa, the French found a higher education system consisting of al-Zitouna and began to modernize it by dividing studies into high, intermediate, and elementary levels. At the same time, the Madrasat al-Zitouna remained conservative and kept the "Islamic tradition alive by carrying out its ritual and legal duties" (Sizer, 1971, p. 6). The French, with pressure from students, eventually established new educational institutions, such as the AlJam'iyyah Al-Khalduniyyah, (named after a famous Tunisian philosopher and historian Ibn Khaldun), which was designed to provide students attending Madrasat al-Zitouna with a European curriculum in addition to an Islamic education (Anderson, 1986). Madrasat alZitounas was viewed by the French as a bastion of cultural resistance against French influence and its official policy towards al-Zitounas as one of isolation, incorporating the 
existing system rather than weakening it since the aim was not to "creat[e] an educated elite who could cause political problems" (DeGorge, 2002, p. 583).

It was not until 1912 that extensive reforms were undertaken when the statute organizing the educational system at the Madrasat al-Zitouna decreed that the institution should have three cycles: (i) al-Ahlya (a primary cycle leading to an Aptitude Degree); (ii) alTahcil (an intermediate cycle resulting in the Proficiency Degree); and (iii) al-Alimy (a higher education cycle leading to the Scholarship Degree). By 1933, the syllabi were revised and the "al-Tatwii" degree was changed to an "al-Tahcil" (comparable the Baccalaureate or "A" levels) (al-Zitouna, 2005). In 1944, the French established the Higher Education Institute of Tunis, the Tunisian School of Management, and the Law Institute. In April 1951, a modern branch was created, and a two-stage al-Tahcil degree was instituted.

By the time Habib Ben Ali Bourguiba (in power from 1957 to 1987) led the country to independence in 1958, Tunisia did not have a higher education system that served the needs of the newly independent nation. Bourguiba's 1958 education reforms focused on the Tunisification - conferring of national identity - of higher education since at independence Tunisia's higher education system consisted of a few agricultural research centers and colonial outposts, such as France's Pasteur Institute in Tunis, and the Ecole Normale Superieure (the Higher Normal School) established in 1956 as the first institution of higher education in independent Tunisia (MOHESRT, 2008). In this way, the process of Tunisification cemented "the post-independence Tunisian government's desire to use education to create citizen-subjects ... in which Westernization and Tunisian Islamic culture would be 'synthesized" (Champagne, 2007, p. 204). Thus, post-independence reforms concentrated on "respond [ing] to the needs of an independent and modern nation that has the ambition to maintain sovereignty and its own personality and to beam both on the regional and worldly environment" (MOHESRT, 2008, p. 18). In Article 25 of the Law on Education No. 58-118, the role of higher education was outlined as:

a) To exempt, in the various domain of sciences, techniques, literature and arts, a culture of the highest level.

b) To contribute in these same domains, to the development and to the continuous progress of the science, conceptions, means and scientific research's methods.

c) To form the researchers and the scholars and to provide the ways and the means in order to enhance the vitality of their creative scientific activity.

d) Ensure the training of the senior executives, scientists, techniques, and nontechniques, necessary for the life of the nation and the teachers of the second degree and to beneficiate the education in its various degrees, of the scientific progress and knowledge. (MOE, 1958, p. 8)

In essence, post-independence higher education was responding to the national need to create a new cadre for the defunct French bureaucratic apparatuses. While Bourguiba's Minister of Education, Mahmoud Al Mesaadi, unified the larger educational system under the process of Arabizing the curriculum in primary and secondary schools, Arabizing at the tertiary level occurred as Madrasat al-Zitounas were reformed into middle schools instead of high schools through the removal of the fifth and sixth grade classes. The process of Tunisification under Bey's Decree No. 98 created the University of Tunis (Universite de Tunis) by merging the School of Fine Arts, the Higher School of Commerce, and Classes of Higher Letters and Special Mathematics of Lycée Carnot into one institution (Siino, 2004). The new university began with six faculties: Natural Sciences, Physics, Mathematics, and 
Science; Medicine and Pharmacy; Law, Political Science, and Economical Science; Letters and Human Sciences; Theology; and Ecole Normale Superieure. In 1969, The National School of Engineers and the Higher Institute of Enterprise Management were created at the University of Tunis and, with time, other institutions were added. As Jules and Barton (2018) argue, the "goals of the Tunisification process were twofold: (i) to create a new cadre of professors at the University of Tunis; and (ii) to keep Tunisian students in the country through three core elements (a) evoking history, (b) enhancing culture and religion and (c) promoting gender equity" (p. 96).

It was toward the end of the 1960s, as the "Tunisian cooperative socialism" experiment lost steam, that higher education reforms were undertaken with the aim of centralizing the system as "the council of the university presidency would be headed by the state secretary of the national education" (MOHESRT, 2008, p. 48) under the government. This period also saw the establishment of new institutes and universities while reinforcing Bourguiba's vision of free access to higher education. The 1976 Education Law emphasized the preservation and reinforcement of national and cultural identity through the systematic teaching of the Arabic language" (MOHESRT, 2008, p. 58). Finally, in 1978, the government divided the Ministry of National Education into two ministries. The Ministry of National Education became responsible for the management of primary and secondary education (technical and professional), and the Ministry of Higher Education and Scientific Research was placed in charge of higher education as well as fundamental and applied research.

When Ben Ali came to power on November 7, 1987, after the medical coup d'état ousted Bourguiba, to his demise on January 14, 2011 , higher education underwent three intensive reform periods: the 1987 reforms, the 1991 reforms, and the 2008 reforms. The first two reforms were unremarkable as they merely built upon Bourguiba's vision of free tertiary education. The first set of reforms, which did not address the issues of unemployment and were a Band-aid solution, expanded access to higher education by constructing several new universities in the interior of the country and splitting the University of Tunis into three institutions: Tunis University I (Faculty of Sciences, Techniques and Medicine); Tunis University II (Faculty of Law, Economics and Management); and Tunis University III (Faculty of Letters, Arts and Human Sciences). The second set of reforms focused on ensuring that higher education (including post-secondary training) and scientific research were complementary and promoted national development. However, these changes failed to achieve their goal of alleviating unemployment and providing the skillsets vital to the labor market.

\section{The Road to Indirect Coercive Transfer and Educational Copying}

Until 2005, under the regime of the first president Bourguiba, university training in the branches listed above lasted four years (with the exception of medical studies, engineering, and architecture). In 1986, the year before Ben Ali took power, there were 3,000 university graduates; by 2005, there were 49,000. Unlike other countries in the Middle East and North Africa (MENA), Tunisia spends a more substantial portion of its GDP on higher education. In 2002, France implemented the Bologna reforms. However, it was not until 2006, that the Ben Ali regime implemented "convergence policies to meet the criteria based on the European Bologna Process” (Temporin, 2014, p. 95). Ben Ali inherited an education system where "the first two decades of independence were devoted to the spread of education [the 1960s] then to Arabization and Tunisification [1970s] . . the present decade [1980] is that of making choices for the future. The critical issue [as Ben Ali saw it, was] how to form the generation of the year 2000" (as cited in Daoud, 1991, p. 4). 
As such, his education reforms were embedded within his authoritarian bargaining agreement, which was a social pact between him and Tunisians that was based on le Changement (the Change). All government activities were then dominated by le Pacte National (the National Pact): political and economic reforms to encourage foreign investment (Borowiec, 1998). The regime was seeking to innovate, and, in so doing, identified exogenous sources of learning to enact new reforms to boost employment and bear down on homegrown militancy, uprisings, and riots. In fact, le Pacte National drew heavily upon the Spanish model that "brought together political actors with independent bases of power in the society and economy, [as well as] institutionalized and symbolized the compromise that had been brokered among them" (Anderson, 1999, p. 4). In education, Ben Ali's social pact translated into preparing a cadre of students who would be ready to transition into the workforce as Tunisia sought foreign investment in an effort to lower the unemployment rate. In this case, the norms, degree, and type of indirect coercive transfer occurring were being promoted by the Tunisian state.

To rectify this, in 2005, Ben Ali's regime embarked upon a set of reforms called "Tunisia Tomorrow," which aimed at creating "a large scientific and technological partnership with the overseas" (MOHESRT, 2008, p. 155). As such, the Higher Education Act of February 25, 2008 was created as a way to "boost the confidence of students and parents, answer societal expectations and employers' needs and confirm the credibility of national degrees abroad" (MOET, 2008, p. 1). It also "intends to metamorphose higher education in the sole aim at the improvement of the quality of its teaching and research services, a better adaptation of the training to the local, regional, and world mutations and a greater enhancement of the students, teachers and researchers' initiative" (MOHESRT, 2008, p. 191). In fact, the Ben Ali regime was explicit in its higher education policy by stipulating that the purpose of the reform was to "fulfill the convergence with the university teaching at the EU countries" (MOHESRT, 2008, p. 207).

In this way, the regime focused on revising the higher education curriculum to bring it in line with the needs of the labor market by developing a system of applied diplomas (applied bachelor's degrees and professional masters) in the form of copying the LMD system from France. Ben Ali's reasoning for copying the LMD system was purely political and based upon buying time, as the regime hoped jobs would eventually materialize, and the restructuring of the higher education system was viewed as giving Tunisians access to a modular and credit system that allowed "flexibility and international comparability" (Ahmed, 2006).

\section{Transitioning, then Copying, and, Finally, Transferability}

The current challenge with indirect coercive copying is that there is no uniform typology across institutional structures. However, the measurement of indirect coercive copying is mainly based on the policy discourse of the "fear" of falling behind on perceived regional or global normative issues. What is clear, is that global governance actors involved in this process are viewed as "predatory agents of policy transfer" (Evans, 2009, p. 256) as they dictate the speed, intensity, and type of reform to be copied. Here we argue that indirect coercive transfer through copying is multidimensional (global, supranational, and local), based on interdependence, and driven by shared externalities. A sketch at a typology may then account for processes of policy mobilization, local articulation and ownership, structural factors, and path dependence. In the current example, this occurred through: (i) emulating a specific global reform that is viewed as in sync with global norms and benchmarks; (ii) quelling fears at home and abroad with regard to government control; (iii) spurring a 
competitive advantage through the preparation of a new cadre of workers for external labor markets as the home market stagnates.

The first step toward indirect coercive transfer in the form of policy mobilization was the "glorification (highlighting the strengths of one's own educational system as a result of comparison" (Steiner-Khamsi, 2003, p. 2) of the then existing system to indicate that the necessary institutional structures were already in place to allow for the successful transplantation of exogenous norms. The specific reform that was emulated was the Sorbonne Declaration of May 25, 1998, aimed at creating a European area of higher education with the goal of promoting students' and teacher's mobility as well as employability. One year later, on June 19, 1999, the reform was concretized by the Bologna Declaration (1999). The Bologna system set out to structure a higher education system similar to the three-cycle American systems of BA/MA/PHD. The system prioritized strengthening quality assurance and recognition of qualifications and periods of study.

The Bologna process was needed to facilitate job and course applications among European countries. The increased compatibility between education systems made students and job seekers more mobile within Europe. The three-cycle system was based on the European Credits Transfer System (ECTS). While the European system allowed five years of negotiation before the Bologna process was adopted, the Ben Ali regime rushed into copying and subsequently transferring the system without disentangling path dependence. The first cycle leads to a bachelor's degree, which is obtained after successful completion of a study program with $180-240$ ECTS credits. The second cycle leads to a master's degree, which is obtained after successful completion of a study program with 60-120 ECTS credits. However, no credits or range of credits has been assigned to the third cycle. Doctoral students have a wide range of study programs apart from conducting independent research.

For the second step, after several elections and promising democratic participation, Ben Ali needed to show international creditors that the government was in control. Thus, the primary impetus for this reform was that since taking office in 1997, Ali's initiatives to expand higher education meant that the student population had tripled from just over 100,000 to close to 400,000 and the unemployment rate averaged 15 percent. Before and after the switch to the LMD system, the government continued to make higher education free and subsidized campus food and student health insurance while students shouldered the cost of books, lodging, and other supplies. Before the 2008 reforms, students began their studies in tertiary education with the "first cycle," which lasted for two years; after which they obtained a Diplôme d'Etudes Universitaires de Premier Cycle (Diploma of University Studies of the First Cycle) (DEUPC) in the technical fields. The DEUPC, viewed as a "preparation phase," was necessary for entry into the technical fields of the second cycle, which lasted an additional two years. Students not in the technical areas spent four years studying for a Maîtrise (Bachelor's Degree), which was the first degree of the Tunisian higher education system. The Diplôme d'Etudes Approfondies (DEA) (Master's Degree) was awarded after two years of studies and the completion of a thesis defense, which was either open or closed, dependent upon the field of study. Holding a Diplôme d'Etudes Approfondies was a prerequisite for admission into a doctoral program that lasted for three years (World Bank, 2008; Jules \& Barton, 2018).

Finally, the new LMD system was touted as way to cure unemployment and underemployment. The LMD system that was transposed is governed by the Act of February 25, 2008, wherein Degrees or Diplomas are referred to as "Cycles." The First Cycle or la Licence (the baccalaureate +3 years) - Diplôme d'Etudes Universitaires du Premier Cycleis undergraduate studies for three years (two of which are general studies and one year is 
professional specialization) after passing the baccalaureate. The Second Cycle or la Maîtrise (the baccalaureate +5 years) is equivalent to a master's degree, where the first year is focused on general studies and the second year on either research or professional specialization. The Third Cycle, or doctorat (the baccalaureate +8 years) - Diploma d'Etudes Approfondies, is a Master of Advanced Studies for three years after la Maîtrise leading to a doctorate. There is also the postsecondary option of attending Higher Institutes of Technological Studies (Instituts Supérieurs des Etudes Technologiques, or ISETs). In moving to the new system, the Ben Ali regime argues that the new reforms provide

(i) the ability to have degrees that are readable and comparable; (ii) the implementation of an academic credit-hour system; (iii) a focus on applied and professional degrees; (iv) encourage labor mobility through credit comparability; (v) internationalization of higher education; (vi) the adoption of a system of easily readable and comparable degrees; (vi) greater institutional autonomy; and (vii) defined state standards for the awarding of all degrees. (Jules \& Barton, 2018, p. 108)

However, the new reforms were only copied in the humanities and other soft subjects, and the hard sciences, particularly the faculties of medicine, engineering, and architecture, were not realigned to the new system. This shows that the Ben Ali regime was a rationalized actor and that one aspect of the reform suffered from "implicit literalism" (Peck \& Theodore, 2001), where the intention was to clone a fully formed off-the-shelf policy. It also alludes to a deliberate and calculative move by the regime to ensure that specific segments of higher education were opened up to market competition, as well as the comparability and flexibility that Europe required of workers in the service industries, while students studying in the hard sciences were kept under the old system. With the removal of the three-year Bachelor course model under the old system, the official policy that exempted the hard science from the LDM reforms advocated that

... (8 years of postsecondary study in medical studies and 6 years in dentist studies, pharmacy and architecture) 5 years of engineering courses, are based on the structure of Bachelor degrees, awarded on accumulation of 180 credits, Master degrees, awarded after a further 120 credits have been accumulated and Doctorates. Engineering students attend two years of preparatory classes, culminating in a national competitive examination and are then assigned to 'les écoles d'ingénieurs' [schools of engineering] on the basis of their grading and their wishes. Specialised training in 'les écoles d'ingénieurs' takes three years, bringing the total length of engineer training to five years. In medical subjects, the number of places is limited to about 200 first-year students in each institution and studies last for five years, followed by one year of clinical training. Courses in paramedical subjects, i.e. health science and technology and nursing, have switched to the Bachelor, Master and Doctorate system. (European Commission TEMPUS, 2010, p. 2)

However, if one reads the official government documents, they suggest that the transition to the LDM system commenced back in 1996, before Ben Ali took power (Ahmed, 2006). It was the 1990s that featured an increase in enrollment in the science and technology faculties after the government shortened the period for completing technical degrees. 
Consequently, between 2000 and 2008, enrollment in these fields doubled (Abdessalem, 2010). However, government documents illustrate that the transition to "the LMD system is a choice made by the State to develop higher education and raise it to the standards of most developed countries as well as to achieve the strategic objectives of the country" (MOET, 2008, p. 18). It was seen as part of the general trend toward the "devolution of spending authority" by decentralizing universities and departments, while, at the same time, encouraging the "assessment grounded upon clear criteria: internal efficiency, external efficiency, pedagogy innovation and pedagogic skills of teachers, scientific output, relationship and partnership with economic environment as well as foreign universities" (Abdessalem, 2010, p. 10). In this way, the LMD system was a tactical maneuver based upon historical notions that the higher education system was failing to provide the necessary talent pool for the labor market; the focus was not on the reform itself, but, rather, how the reform was to be perceived by others. In other words, the reform aimed to "enhance Tunisia's place in the world" (TECA, 1992, p. 6). Moreover, it showed that Tunisia was willing to liberalize its 'educational services.' As such, the LMD system was phased in simultaneously with the old system, and no significant institutional investment or expansions were made.

Therefore, the LMD was implemented to achieve a shift towards European standards that allowed for the "adoption of an easily comparable and equivalent degree system... [as well as ] teaching quality and the development of professionalization with regards to higher education studies leading to diplomas more suited to the national and global job market" (Temporin, 2014, p. 95). The LMD reforms became tied to employability, while universities were positioned at the epicenter of economic development as the reform sought to develop public-private partnerships with industries. In strengthening its commitment to indirect coercive transfer, in 2009, the Tunisia government attended the First Bologna Policy Forum, which called for mutual learning and sustainable cooperation. At the Second Bologna Policy Forum in 2010, which Tunisia also attended, it was recognized that Bologna was redefining Europe, and countries outside of the area were increasing their level of cooperation with Bologna countries.

In fact, it was the rhetoric of the challenges and opportunities of "brain circulation" that the Ben Ali regime used to legitimize its rush to implement Bologna as a way to give students' flexibility in their study curriculum. The implementation of the LMD system was not seen as one of translation, nor diffusion, nor cross-national policy learning, nor based on bounded rationality, but one driven by internal pressure (creating jobs) and external force (cooperating with the rest of Europe). It was also not random or unfocused, but strategically translated; however, it was not adequately deciphered. The LMD, with its combination of something new (soft sciences) and something old (hard sciences), became a unique assemblage that was indicative of both local and extra-local impositions. When viewed from the vantage point of an assemblage, the LMD system is then in the process of coming together though territorialization and can easily be deterritorialized. However, in reality, the LMD reform did not tackle other historical dependencies such as lack of resources, employability, and labor market dynamics.

\section{Assessing Indirect Coercive Transfer and Educational Copying}

While the literature speaks to the transfer of "negative lessons" (Dolowitz and Marsh, 2000), the reform of the LMD system, which started in 2006-07, was one of indirect coercive transfer. The Ben Ali regime was indirectly coerced into adopting the Bologna system, even though this specific reform was unnecessary. This type of transfer, which is a multidimensional power-laden process, is different in authoritarian spaces from that of free 
market settings in that the benevolent dictator has the ability to ensure that all the requisite elements of the reforms are transplanted. In transferring policy ideas and norms to the Tunisian system, the Ben Ali regime did not take into consideration contextual constraints that would lead to the copying of negative lessons. In fact, the research on the programmatic complexity of transfer suggests that it is mitigated by several factors ranging from path dependency, structural and institutional obstructions to ideological incompatibility, and insufficient technological, economic, bureaucratic and political capacity (Benson \& Jordan, 2011 ; Dolowitz \& Marsh, 1996).

Arguably, the Ben Ali regime did not sufficiently consider that translation, transformation, and transfer of policy models, which are often embedded with mutations and are power-laden; therefore, the reform needs to be recontextualized appropriately. The transition to the LMD system has been gradual and in three waves: the first application of the LMD system was in September 2006. This application created an artificial demand for higher education since it was thought that the historical background which has privileged other reforms added to policy layering. The second wave was applied in September 2007. The last wave was adopted in September 2008. The higher institutions were free to set the deadline for their reform. During the transition periods and the coexistence of the two systems, the students retained all the rights that the current system entitled to them. In 2012, the LMD system was generalized in all Tunisian higher education institutions. The LMD system was established after consultation with the universities, teachers, and students, together with stakeholder associations. Different objectives were set by the Tunisian ministry of higher education when establishing the LMD system:

- Build a training system characterized by flexibility and international comparability

- Reform programs and diversify career paths

- Create flexible and efficient training paths including both academic and applied trainings, in order to offer students, at all levels, opportunities for professional integration

- Promote student's mobility on a national and international scale

- Facilitate the equivalence of diplomas

- Create a new generation of graduates who can adapt to a changing global context. (MOHER, 2006, p. 3)

After a three-year period following the baccalaureate exam, the university training leads to a national diploma (Licence or Bachelor's degree). All courses offered by the Tunisian universities, except medical, architecture and engineering courses, can be categorized into two types of studies: fundamental or academic studies, and applied or professional studies. As such, indirect coercive transfer was not viewed as an independent process, but it was seen as a part of a broader policy process to deliver new jobs.

The Applied Licence is principally intended to allow student holders to join the labor market immediately. Also, it allows the most brilliant students within the limits of their capacity, to achieve a professional master's degree. Similarly, the Fundamental Licence allows student holders to immediately begin their search for jobs. It permits the best students to apply, within the limits of the capacity of the universities, for a research master's degree or a professional master's degree. The academic (Fundamental) training is equivalent to 180 ECTS (over six semesters). The semester is comprised of fourteen weeks of study and consists 
of five or six teaching units representing thirty ECTS. It is worth noting that students wanting to attend engineering schools have to first participate in two years of preparatory classes, culminating in a national competitive examination. The scores achieved in this national exam are used to enroll students in various engineering schools. Specialized training in the engineering schools is delivered over three years, bringing the total length of engineering training to five years. Preparation for medical studies lasts five years. Courses in paramedical subjects, i.e. health sciences, technology, and nursing, have been adapted to the Bachelor, Master, and Doctorate system.

In theory, the Tunisian higher education system says that it aims to provide sound academic training. The primary objective of the reform proposed by the Ministry of Higher Education and Scientific Research is to curtail the growing challenge of unemployment among graduates. However, the unemployment rate remained persistently high mainly among young graduates, with some estimates suggesting 44 percent of recent graduates were unemployed (Wolf \& Lefévre, 2012). Over the past ten years, unemployment was above 13 percent. Between 1990 and 2010, the section of the population aged 15 or older with a tertiary education nearly quadrupled from 3.7 percent to 12.3 percent (World Bank, 2014). The Tunisian economy is characterized by low productivity and was, therefore, unable to absorb the bulk of university graduates. By the end of 2012, over 30 percent of graduates with university degrees were jobless.

In the end, the reform under indirect coercive transfer failed as it ended up producing workers who did not have the skills needed to function in the labor market. In the post-2011 period, this would be a problem as it resulted in Tunisia creating a cadre of foot soldiers that the Islamic State would later recruit, train, and radicalize, who would then return and conduct homegrown terror incidents; for instance, the Bardo National Museum attack on March 18, 2015; the Sousse beach hotel attacks on June 26, 2015, and the Tunis bus bombing on 24 November 2015). In summary, the Tunisia case study serves as an example of the deleterious effects of exogenous pressures on governments to participate in regional and global initiatives through the process of interest coercive transfer. These exogenous forces do not take into consideration whether the local context is ripe for policy learning, translation, diffusion, or copying.

\section{References}

Abdessalem, T. (2010). Financing higher education in Tunisia (Working Paper No. 551), Egypt: The Economic Research Forum. Retrieved from http://erf.org.eg/wpcontent/uploads/2014/08/551.pdf

Anderson, L. (1999). Politics in the Middle East: Opportunities and limits in the quest for theory. In M. Tessler, J. Nachtwey \& A. Banda (Eds.), Area studies and social science: strategies for understanding Middle East politics (pp. 1-10). Bloomington: Indiana University Press.

Ahmed, K. (2006). University Libraries in the South: From virtual to real. Information Development, 22(4), 252-262.

Bache, I., \& Taylor, A. (2003). The politics of policy resistance: reconstructing higher education in Kosovo. Journal of Public Policy, 23(3), 279-300.

Ball, S. J. (1990). Politics and policy making in education. London: Routledge.

Bazbauers, A. (2017). World Bank Technical Assistance: The Relational Dynamics of Policy Movement. Public Administration and Development, 37(4), 246-259. 
Beech, J. (2006). The theme of educational transfer in comparative education: A view over time. Research in Comparative and International Education, 1(1), 2-13.

Beech, J. (2011). Global Panaceas, Local Realities: International Agencies and the Future of Education. Frankfurt Am Main, Germany: Peter Lang.

Beech, J. (2012). Education policy transfer in an era of globalization: Theory-historycomparison. Frankfurt am Main, Germany: Peter Lang.

Bennett, C. (1991). What is policy convergence and what causes it? British Journal of Political Science, 21(2), 215-233.

Benson, D., \& Jordan, A. (2011). What have we learned from policy transfer research? Dolowitz and Marsh revisited. Political Studies Review, 9(3), 366-378.

Bologna Declaration (1999). The Bologna Declaration of 19 June 1999: Joint declaration of the European Ministers of Education. Retrieved From https://www.eurashe.eu/library/modernising-phe/Bologna_1999_BolognaDeclaration.pdf.

Bulmer, S., Dolowitz, D., Humphreys, P. \& Padgett, S. (2007). Policy transfer in the European Union. London: Routledge.

Champagne, J. (2007). "Job seekers" and "enterprise incubator": Educational reform in Tunisia. Changing English, 14(2), 201-215.

Crossley, M. (1984). Strategies for curriculum change and the question of international transfer. Journal of Curriculum Studies, 16(1), 75-88.

Crossley, M. (1999). Reconceptualizing comparative and international education. Compare: A Journal of Comparative and International Education, 29(3), 249-267.

Crossley, M., Bray, M., \& Packer, S. (2011). Education in small states: policies and priorities. London, UK: The Commonwealth Secretariat.

Daoud, M. (1991). Arabization in Tunisia: The tug of war. Issues in Applied Linguistics, 2(1). Retrieved from http://escholarship.org/uc/item/3v1089k4.

DeGorge, B. (2002). The modernization of education: A case study of Tunisia and Morocco. The European Legacy, 7(5), 579-596.

Dolowitz, D. P. \& Marsh, D. (1996). Who learns what from whom? A review of the policy transfer literature. Political Studies, 44(2), 343-57.

Dolowitz, D. P. \& Marsh, D. (2000). Learning from abroad: The role of policy transfer in contemporary policy making. Governance, 13(1), 5-24.

Dussauge-Laguna, M. I. (2012). On the past and future of policy transfer research: Benson and Jordan revisited. Political Studies Review, 10(3), 313-324.

El-Mesawi, M. T. (2008). Muslim reformist action in nineteenth-century Tunisia. The American Journal of Islamic Social Sciences, 25(2), 49-82.

Evans, M. (2009). Policy transfer in critical perspective. Policy Studies, 30(3), 243-68.

European Commission (TEMPUS). (2010). Higher education in Tunisia, European Commission. Retrieved from

http://eacea.ec.europa.eu/tempus/participating_countries/reviews/tunisia_review_of_h igher_education.pdf.

Fryer, L. G, \& Jules, T. D. (2013). Policy spaces and educational development in the Islamic Maghreb region: Higher education in Tunisia. In A. W. Wiseman \& C. C. Wolhuter (Eds.), The development of Higher Education in Africa: Prospects and Challenges (pp. 401-425). Bingley, UK: Emerald Publishing. 
Gyimah-Brempong, K., \& Ondiege, P. (2011). Reforming higher education: Access, equity, and financing in Botswana, Ethiopia, Kenya, South Africa, and Tunisia. In World Bank and the African Development Bank (Eds.). The Africa competitiveness report 2011 (pp. 39-111). World Economic Forum.

Hartmann, E. (2008). Bologna Goes Global: A New Imperialism in the Making? Globalisation, Societies and Education, 6(3), 207-220.

Holmes, K. \& M. Crossley, M. (2004). Whose Knowledge, Whose Values? The Contribution of Local Knowledge to Education Policy Processes: A Case Study of Research Development Initiatives in the Small State of Saint Lucia. Compare: A Journal of Comparative and International Education, 34(2), 197-214.

Ikenberry, J. G., (1990). The international Spread of Privatization Policies: Inducements, Learning and Policy Bandwaggoning. In E. Suleiman \& J. Waterbury (Eds.). The Political Economy of Public Sector Reform. Boulder: Westview Press.

Jayasuriya, K., \& Robertson, S. L. (2010). Regulatory Regionalism and the Governance of Higher Education. Globalisation, Societies and Education, 8(1), 1- 6.

Jules, T. D. (2008). Re/thinking harmonization in the commonwealth Caribbean: Audiences, actors, interests, and educational policy formation (Doctoral dissertation). New York, Columbia University: Teachers College.

Jules, T. D. (2010). Beyond post-socialist conversions: functional cooperation and transregional regimes in the Global South. In I. Silova (Ed.). Post-socialism is not dead: (Re) reading the global in comparative education (pp. 401-426). Emerald, Bingley UK.

Jules, T. D. (2012). Neither world polity nor local or national societies: Regionalization in the Global South - The Caribbean Community. Berlin, Germany: Peter Lang.

Jules, T. D. (2015). The Caribbean educational policy space: Educational gradualism, zerosum policy reforms, and lesson-drawing in small (and micro) states. Journal of Supranational Policies of Education, 3, 307-329.

Jules, T. D, \& Barton, T. (2018). Educational transitions in post-revolutionary spaces: Islam, security and social movements in Tunisia. London: Bloomsbury Academic.

Jules, T. D., \& Silva, M. M. (2008). How different disciplines have approached South-South cooperation and transfer. Society for International Education Journal, 5(1), 45-64. Retrieved from http://www.tc.columbia.edu/sie/journal/Volume_5/jules.pdf.

Lam, E. (2010). Sharing best practices in Barbados and Trinidad and Tobago: Patterns of policy implementation and resistance. Compare: A Journal of Comparative and International Education, 41(1), 25-41.

Lange, M. (2013). Comparative-historical methods: An introduction. In M. Lange (Ed.), Comparative-historical methods (pp. 1-21). New York, NY: Sage Publications.

Louisy, P. (2001). Globalisation and comparative education: A Caribbean perspective. Comparative Education, 37(4), 425-438.

Mahoney, J., \& Rueschemeyer, D. (2003). Comparative historical analysis: Achievements and agendas. In J. Mahoney and D. Rueschemeyer (Eds.), Comparative historical analysis in the social sciences (pp. 3-38). Cambridge, UK: Cambridge University Press.

Mamadouh, V., de Jong, M. \& Lalenis, K. (2003). An Introduction to institutional transplantation. Discussion Paper Series, 9(13), Department of Planning and Regional Development, University of Thessaly.

Marginson, S., \& Wende, M. V. D. (2007). Globalisation and Higher Education. Education Working Paper 8. Paris: OECD. 
Massey, A. (2009). Policy Mimesis in the context of global governance. Policy Studies, 30(3), 383-95.

McCann, E., \& Ward, K. (2012). Policy assemblages, mobilities and mutations: Toward a multidisciplinary conversation. Political Studies Review, 10(3), 325-332.

MOE (1958). Law of November 4, 1958. Tunis, Tunisia: Government of Tunisia.

MOHER (2006). La Réforme LMD en Tunisie note de cadrage. Retrieved from http://www.isetkr.rnu.tn/new/pdfs/note_de_cadrage_LMD_Version-Francaise.pdf

MOHESRT (2008). The fiftieth anniversary of the Tunisian university, 1958-2008. Tunis, Tunisia: Government of Tunisia.

Peck, J. \& Theodore, N. (2001). Exporting workfare/importing welfare-to-work: Exploring the politics of third way policy transfer. Political Geography, 20(4), 427-60.

Peck, J. \& Theodore, N. (2010). Mobilizing policy: Models, methods, and mutations. Geoforum, 41(2), 169-74.

Phillips, D. (2004). Toward a theory of policy attraction in education. In G. Steiner-Khamsi (Ed.). Lessons from elsewhere: The politics of educational borrowing and lending (pp. 54-67). New York: Teachers College Press.

Phillips, D., \& Ochs, K. (2004). Researching policy borrowing: Some methodological problems in comparative education. British Education Review Journal, 30(6), 773-784.

Rappleye, J. (2006). Theorizing educational transfer: Toward a conceptual map of the context of cross-national attraction. Research in Comparative and International Education, 1(3), 223-240.

Rappleye, J. \& Paulson, J. (2007). Educational transfer in situations affected by conflict: Towards a common research endeavour. Research in Comparative and International Education, 2(3), 252-271.

Robertson, S., Banal, X., \& Dale, R. (2002). GATS and the education services industry: The politics of scale and global reterritorialization. Comparative Education Review, 46(4), 472-496.

Rose, R. (1993). Lesson drawing in public policy. Chatham: Chatham House.

Rose, R. (2005). Learning from Comparative Public Policy: A Practical Guide. London: Routledge.

Rose, R. (2006). Policy transfer, policy learning, policy convergence, policy diffusion. Retrieved

from http://www.abdn.ac.uk/pir/notes05/Level3/PI3549/Week\%207.1\%20Policy\%20Trans fer.doc.

Shore, C. \& Wright, S. (1997). Policy: A new field of anthropology. In C. Shore \& S. Wright (Eds.). Anthropology of policy: Critical perspectives on governance and power (pp. 339). London: Routledge.

Siino, F. (2004). Science et pouvoir dans la Tunisie contemporaine. Paris/Aix-en-Provence: Karthala Editions.

Silova I. (2009). Varieties of educational transformation: The post-Socialist states of Central/Southeastern Europe and the former Soviet Union. In R. Cowen R., \& A.M. Kazamias (Eds.). International Handbook of Comparative Education (pp.295-320). Dordrecht: Springer.

Sizer, C. T. (1971). The development of education in Tunisia. (unpublished master's dissertation). The American University, Washington, DC. 
Steiner-Khamsi, G. (2003). The politics of league tables. Journal of Social Science Education Retrieved from http://www.sowi-onlinejournal.de/2003-1/tables_khamsi.htm.

Stone. D. (2001). Learning lessons, policy transfer and the international diffusion of policy ideas. Centre for the Study of Globalisation and Regionalisation (CSGR), University of Warwick, Coventry, CV4 7AL: United Kingdom.

Stone, D. (2004). Transfer agents and global networks in the "transnationalization" of policy. Journal of European Public Policy, 11(3), 545-66.

TECA (Tunisian External Communications Agency). (1992). The national pact. Tunis:TECA.

Temporin, S. (2014). Higher education and society in Tunisia: re-thinking university and students social responsibility. Hemispheres, 29(3), 85.

Vavruz, F. (2004). The referential web: Externalization beyond education in Tanzania. In G. Steiner-Khamsi (Ed.). The global politics of educational borrowing and lending (pp. 141-153). New York: Teachers College Press.

Verger, A., \& Hermo, J. P. (2010). The governance of higher education regionalisation: Comparative analysis of the bologna process and MERCOSUR-Educativo. Globalisation, Societies and Education, 8(1), 105-120.

Waldow, F. (2009). Undeclared imports: silent borrowing in educational policy-making and research in Sweden. Comparative Education, 45(4), 477-494.

Wedel, J. R., Shore, C., Feldman, G. \& Lathrop, S. (2005). Toward an anthropology of public policy. Annals of the American Academy of Political and Social Science, 600(1), 3051.

Wolf, A., \& Lefévre, R. (2012, April 18). Tunisia: A revolution at risk. The Guardian. Retrieved from http://www.guardian.co.uk/commentisfree/2012/apr/18/tunisiarevolutionat-Risk.

World Bank (2008). The road not traveled; education reform in the Middle East and North Africa. Washington, DC: The International Bank for Reconstruction and Development/The World Bank. Retrieved from http://siteresources.worldbank.org/INTMENA/Resources/EDU_Flagship_Full_ENG. pdf.

World Bank (2014). The unfinished Revolution: Bringing opportunity, good jobs and greater wealth to all Tunisians. Retrieved From http://www.worldbank.org/en/country/tunisia/publication/unfinished-revolution

Xheneti, M., \& Kitching, J. (2011). From discourse to implementation: enterprise policy development in postcommunist Albania. Environment and Planning C: Government and Policy, 29(6), 1018-1036.

\footnotetext{
About the Authors

Tavis D. Jules is an Associate Professor of Cultural and Educational Policy at Loyola University Chicago, specifically focusing on Comparative and International Education and International Higher Education. His vast professional and academic experiences have led to research interests in human rights, regionalism and governance, transitory and authoritarian spaces, and policy challenges in small island developing states (SIDS), the Caribbean and North Africa. His most recent books include Educational Transitions in Post-Revolutionary Spaces: Islam, Security and Social Movements in Tunisia (with Teresa Barton, 2018); Re-Reading Education Policy and Practice in Small States: Issues of Size and Scale in the Emerging Intelligent Society and Economy (with Patrick Ressler, 2017); and The New Global Educational Policy Environment in the Fourth Industrial Revolution: Gated, Regulated and Governed (2016).
} 
Donia Smaali Bouhlila is an Assistant Professor at faculté des sciences économiques et de gestion de Tunis El Manar. She holds a Ph.D in development economics. She is a researchassociate at the Economic Research Forum and at Laboratoire Prospectives, Stratégies et Développement Durable (PS2D).She has published major papers in English. She is a board member in the International Journal of Educational Development. As a developmenteconomist, she is interested in a variety of topics including the quality of education in the Middle East and North Africa, the impact of child labor on education, poverty, and educationviolence against women nexus. 